\section{From silos to ecosystems}

Editor's note: This month's Washington Hotline department features a guest column by Rachel Minkin, head of Reference Services at Michigan State and a member of the ALA Committee on Library Advocacy's Ecosystem Subcommittee.

When library professionals talk about silos, we focus internally - technical services, public services, digital services, etc. Outside of individual libraries, we see more silos—public libraries, K-12 libraries, special libraries, state libraries. The most siloed, of course, are the academic libraries, ensconced firmly in our ivory towers (a perception from both within and without). Within our larger library associations, we keep those same silos, taking great care to advocate for our library type- the needs of our patrons and work. What if we take one more giant step back to see an even larger picture that sees each silo as a node in a greater library ecosystem? What happens when we see the interconnectedness of all library types within a whole state?

ACRL Insider readers have probably already seen the guest post from COLA Library Ecosystem Subcommittee Co-Chairs Dorcas Hand and Sara Kelly Johns. ${ }^{1}$ As a current member of this subcommittee (and the previous workgroup), I want to share how this works here in Michigan. We have an ACRL chapter within the Michigan Library Association (MLA), keeping a voice in collaboration with MLA's heavy public library focus; the Michigan Academic Library Association (MiALA), which is also an ACRL Chapter and my home chapter; the Library of Michigan (an active state library); the Michigan Association for Media in Education (MAME) for school librarians; and the Midwest Collaborative for Library Services. Interspersed, we have smaller organizations and associations, some disciplinespecific, some skill- and expertise-specific.

Under the context of library ecosystems, Michigan's academic library "node" in this ecosystem is no ivory tower that is off by itself. Although our funding and budgeting processes, staffing needs, and patron groups are different, we face the same types of challenges as our

Rachel Minkin is head of Reference Services at Michigan State University and a member of the ALA Committee on Library Advocacy's Ecosystem Subcommittee, email: minkinr@msu.edu colleagues in other types of libraries. We all strive to remain relevant to and for our patrons, we all manage collections and technology and staffing. We all advocate for budgets to support this on our campuses and to the legislature. We all face a shared history of racism and xenophobia built into our profession. We all advocate for the policies that support all library types because all library types support lifelong learning. Speaking together with One Voice reminds the public that libraries are essential at every stage of life. MiALA, a newer organization, struggled with statewide advocacy in its earliest days. Was that our mission? Was that at odds with the MLA's advocacy? Would we be duplicating efforts already in place? Not even ten years later, we share statewide advocacy efforts in support of our school librarian colleagues, our frontline worker colleagues, and in support of policies protecting patron privacy. This year, we stand with school librarians, Library of Michigan professionals, and public librarians in support of issues, such as Broadband Access, Open Educational Resources, our shared statewide e-resources, and Childhood Literacy at Michigan's Library Advocacy Day. ${ }^{2}$

Michigan's April 2021 Advocacy Day indicates that our collective efforts reflect on evolving application of the ALA One Voice Toolkit, an effort we can continue to build. We are evolving our skills in the core areas of leadership, communication, collaboration, and sustainability. As we increase our capacity in these core competencies, we are strengthening the overall flexibility and resilience with the library ecosystem.

Advocacy for all libraries (and their services and their patrons) is strongest when we effectively work together across all library types. I urge you to bring together the leadership of all library types and the state library to consider the value of working together. As the One Voice Toolkit's definition states, "When we stand together in mutual support using common messaging themes that demonstrate this interconnectedness, every library is stronger."3

\section{Notes}

1. https://acrl.ala.org/acrlinsider/one-voice -building-a-strong-library-ecosystem/.

2. https://www.milibraries.org/advocacy-day.

3. http://www.ala.org/advocacy/state -ecosystem-initiative. $\mathbf{z}$ 